INTIQAD: JURNAL AGAMA DAN PENDIDIKAN ISLAM

ISSN 1979-9950 (print) || ISSN 2598-0033 (online), http://jurnal.umsu.ac.id/index.php/intiqad

DOI: 10.30596/intiqad.v12i2.5321

Vol. 12, No. 2 (December 2020)

\title{
Revitalisasi Pendidikan Agama Islam dalam Mewujudkan Profil Ulil Albab di Perguruan Tinggi
}

\author{
Syahdara Anisa Makruf ${ }^{1^{*}}$ \\ Universitas Islam Indonesia*1, \\ ${ }^{*}$ email:133100508@uii.ac.id
}

\begin{abstract}
Universitas Islam Indonesia is the first and oldest university in Indonesia. Its existence as a university that represents Islamic values that carry out the mission of Rahmatan Lil Alamin to form students has a profile Ulil Albab through the process of coaching Islamic Religious Education carried out comprehensive This research method uses a qualitative naturalistic approach because the author is directly involved in the development activities of Islamic Religious Education at the Islamic University of Indonesia. The research subjects here are the Directorate of Islamic Religious Education (DPPAI) and lecturers of The Compulsory Uumum Lecture (MKWU) of Islamic Religious Education with research objects of PAI coaching activities. As for data analysts by reducing, presenting the data, and concluding. The results in this study found that the history of the establishment of the Ithe Islamic University of Indonesia is to bring together science and religion. Islamic Education development strategies include the establishment of Islamic personality through the planting of Islamic Basic Values (PNDI) and prophetic leadership through Basic Islamic Leadership Training (LKID) while learning strategies include transformative skills and integrative learning. This strategy needs to be revitalized because the Islamic University of Indonesia has the mind as a scientific center, Islamic center, an innovation center to spread the treatise of Islam Rahmatan Lil Alamin.
\end{abstract}

Keywords: Islamic Religious Education, Ulil Albab,
Rahmatan Lil Alamin. Abstrak

Universitas Islam Indonesia merupakan Universitas pertama dan tertua di Indonesia. Keberadaannya sebagai universitas yang merepresentasikan nilai-nilai Islam yang mengemban misi Rahmatan lil'aalamin dengan tujuan membentuk mahasiswa memilikiprofil ulil albab melalui proses pembinaan Pendidikan Agama Islam yang dilaksanakan

Artikel Info

Received:

23 September 2020

Revised:

18 October 2020

Accepted:

28 November 2020

Published:

03 December 2020 
secara komperhensif. Metode penelitian ini menggunakan pendekatan naturalistik kualitatif dikarenakan penulis terlibat langsung dalam kegiatan pembinaan Pendidikan Agama Islam di Universitas Islam Indonesia. Subyek penelitian disini adalah Direktorat Pembinaan Pendidikan Agama Islam (DPPAI) dan dosen pengampu Mata Kuliah Wajib Umum (MKWU) dalam Pendidikan Agama Islam dengan obyek penelitian kegiatan pembinaan PAI. Adapun analis data dengan mereduksi, menyajikan data dan menyimpulkan. Hasil dalam penelitian ini ditemukan bahwa sejarah berdirinya Universitas Islam Indonesia adalah untuk mempertemukan ilmu dan agama. Strategi pembinaan Pendidikan Agama Islam meliputi pembentukan kepribadian Islami melalui kegiatan Penanaman Nilai Dasar Islam (PNDI) dan kepemimpinan profetik melalui Latihan kepemimpinan Islam Dasar (LKID) sedangkan strategi pembelajaran meliputi keterampilan transformatif dan pembelajaran integratif. Strategi ini perlu divitalkan kembali dikarenakan Universitas Islam Indonesia memiliki cita cita sebagai pusat keilmuan, pusat Islam, dan pusat inovasi dalam rangka menyebarkan risalah Islam yang Rahmatan lil'aalamiin.

\section{Kata Kunci: Pendidikan Agama Islam, Ulil Albab, Rahmatan Lil'aalamin.}

\section{A. Pendahuluan}

Setiap Perguruan Tinggi (PT) memiliki kurikulum khasnya masing masing. Hal ini disesuaikan dengan visi dan misi yang dicanangkan. Dalam proses mengimplementasikan tentu ada hambatan. Akan tetapi hambatan ini akan terselesaikan jika terdapatnya desain kurikulum yang baik. Perguruan Tinggi yang bernuansa keislaman memberikan pengaruh pada desain kurikulum, sehingga dalam melaksanakan proses pendidikan berdasarkan pada nilai nilai ajaran Islam. Perguruan Tinggi Umum (PTU) diwajibkan mengelola dan melaksanakan Pendidikan Agama Islam secara komperhensif. Hal ini merupakan hak bagi setiap mahasiswa Islam untuk mendalami nilai nilai keislaman secara universal. Pernyataan ini tertulis dalam UU No 20 Tahun 2003 terkait dengan Sistem Pendidikan Nasional Bab V tentang peserta didik yang terdapat pada 
pasal 12 ayat 1 , menyatakan bahwa setiap siswa atau mahasiswa (peserta didik) yang mengikuti sebuah pendidikan memiliki hak untuk memperoleh pendidikan agama yang disesuaikan dengan agama yang dipeluknya serta diajarkan oleh guru atau dosen yang memiliki agama yang sama.

Selain itu merujuk pada Bab X tentang kurikulum yang terdapat pada pasal 37 ayat 32 tentang kurikulum Pendidikan Agama Islam, wajib mengajarkan Pendidikan

Kewarganegaraan dan Bahasa Indonesia (Rifqi Amin, 2014).

Dalam mengembangkan kurikulum Pendidikan Agama Islam diperlukan adanya proses menyusun, melaksanakan dan menyempurnakan. Keberhasilan pengembangan kurikulum dibangun atas empat asas yakni filosofis, sosiologis, organisatoris dan psikologis. Disisi lain dalam proses pengembangan perlunya pendekatan yakni subjek akademik, humanistik, teknologi dan rekonstruksi sosial sehingga mampu meningatkan mutu Pendidikan Agama Islam (Hanafi, 2014). Salah satu Perguruan Tinggi Umum yang menyelenggarakan Pendidikan Agama Islam secara komperhensif adalah Universitas Islam Indonesia.

Universitas Islam Indonesia sendiri merupakan salah satu Universitas pertama dan tertua di Indonesia. Keberadaannya sebagai universitas yang merepresentasikan nilai-nilai Islam yang mengemban misi rahmatan lil'aalamin melalui pendidikan.

Didirikan sebelum Indonesia merdeka yakni pada 27 Rajab $1364 \mathrm{H}$ atau bertepatan pada tanggal 8 Juli 1945 . Para pendiri pun sekaligus terlibat dalam pendiri Republik Indonesia. Maka dari itu, mendiskusikan sejarah tentang Universitas Islam Indonesia tidak bisa terlepas dengan sejarah kemerdekaan Republik Indonesia (Suwarsono Muhammad, 2020).

Revitalisasi Pendidikan Agama Islam di Universitas Islam Indonesia, didasari oleh realitas yang menganggap bahwa Pendidikan Agama Islam ini kurang begitu penting untuk dilaksanakan. Adanya kelemahan dalam merespon program tersebut, maka perlu kiranya tindakan yang mampu menvitalkan kembali yakni dengan tetap melaksanakan Pendidikan Agama Islam secara holistik sehingga misiUniversitas Islam Indonesia dapat tercapai yakni 
terbentuknya profil lulusan yang ulil albab.

Hal ini termaktub dalam kurikulum komprehensif ulil albab sebagai kurikulum khas Universitas Islam Indonesia. Rumusan profil lulusan Universitas Islam Indonesia berlaku pada seluruh jenjang pendidikan yang ada di Universitas Islam Indonesia meliputi diploma atau vokasi, strata satu, jenjang profesi, program magister dan doktor. Secara tersurat lulusan Universitas Islam Indonesia dicerminkan sebagai Lulusan UII diharapkan mampu menjadi Insan Ulil Albab yakni insan yang memiliki kepribadian yang berlandaskan nilai-nilai Islami, berpengetahuan integratif (terpadu), berkepemimpinan seperti nabi (profetik) dan berketerampilan transformative (UII, 2017)."

Ciri khas yang terdapat dalam rumusan ini yaitu mempunyai ghiroh yang sangat kuat, yakni menvitalkan kembali pada harapan para tokoh pendiri Universitas Islam Indonesia. Dalam teks resmi dariMohammad Hatta sebagai salah satu founding fathers Universitas Islam Indonesia yang merangkap sebagai Wakil Presiden RI ke-1 menjelaskan landasan ideologi keilmuan Universitas
Islam Indonesia sebagai perwujudan dari sekolah Tinggi Islam (UII) yang dapat membentuk ulama atau tokoh agama yang memiliki ilmu pengetahun serta memiliki pendirian yang luas serta semangat juang yang tinggi. Sebab ulama seperti itu yang dianggap mampu untuk menjadi pengajar di tengah masyarakat dalam pengertian yang sesungguhnya. Lebih spesifik lagi, ulama yang memiliki ilmu tersebut akan membawa masyakat dalam kesejahtraan (UII, 2017)".

Dalam rangka merevitalisasi Pembelajaran Agama Islam merupakan perihal yang vital, mengingat jika di dalam kurikulum Ulil Albabterdapat upaya menciptakan kembali peninggalan sejarah para pendiri Universitas Islam Indonesia yakni mempertemukan ilmu agama serta ilmu universal dalam satu kesatuan buat membentuk mahasiswa yang memiliki karakter ulil albab (UII, 2017).

Dalam mengangkat penelitian ini, penulis melakukan kajian literatur tentang revitalisasi, sehingga menemukan beberapa publikasi diantaranya tulisan dari Zalik Nuryana dengan berkaitan dengan upaya revitalisasi pendidikan Al-Islam dan 
Kemuhammadiyah di perguruan tinggi Muhammadiyah. Penelitian ini menemukan bahwa pendidikan AIK merupakan jati diri dalam Perguruan Muhammadiyah. Berangkat dari misi besar pendidikan Muhammadiyah yakni menjadi solusi terhadap keringnya ruh keagamaan dalam pendidikan maka AIK divitalkan karena internalisasi nilai nilai pendidikan yang terdapat di Muhammadiyah mempunyai empat fungsi utama yakni menjadi sarana pencerdasan, sebagai pelayan masyarakat, sebagai proses dakwah amar ma'ruf nahi munkar dan terakhir sebagai fungsi anak panah Muhammadiyah (Zalik Nuryana, 2017).

Kedua, publikasi Muhammad Arif yang meniliti tentang revitaliasi pendidikan Ahli Sunnah Wal Jama'ah (Ke-NU-An) yang dijalankan dengan upaya mencegah faham radikalisme di SMK Al-Azhar Menganti Gresik. Arif menyatakan pendidikan Aswaja AnNahdliyah dalam rangka menangkal faham radikalisme di sekolah tersebut dan menjadikan madrasah sebagai tempat dalam mengawal ideologi Islam Rahmatan Lil Alaamin. Program pencegahan faham radikalisme dilakukan sejak proses penerimaan santri baru. Mereka diharuskan utuk mengkaji ilmu Ahli Sunnah Wal Jama'ah dan membaca kitab ta'lim muta'lim (Muhammad Arif, 2018).

Ketiga Publikasi Andri Moewashi Idharoel Haq dan Muhammad Thariq Aziz dengan topik revitalisasi penddiikan karakter melalui proses penanaman nilai Islam di Universitas Muhammadiyah Sukabumi. Andri menvitalkan bahwa di Universitas Muhammadiyah Sukabumi setiap mahasiswa diharuskan untuk mendapatkan pendidikan karakter. Baginya, salah satu kunci keberhasilan dalam mewujudkan lulusan yang berkualitas di Universitas Muhammadiyah Sukabumi adalah dengan membentuk mahasiswa yang berkarakter (Andri Moewashi Idharoelhaq, 2018).

Dari beberapa kajian literatur di atas, bahwa revitalisasi pendidikan menjadi urgensi bagi setiap penyelenggara pendidikan. Penulis tertarik untuk mengungkapkan bagaimana merevitalisasi Pendidikan Agama Islam dalam kurikulum khas Universitas Islam Indonesia dalam rangka mewujudkan lulusan ulil albab, sehingga riset ini bertujuan buat 
menvitalkan Pembelajaran Agama Islam di Perguruan Teratas yang dilaksanakan sesuai dengan pertumbuhan saat ini.

\section{B. Metode Penelitian}

Tipe riset ini merupakan riset permasalahan. Riset permasalahan atau studi kasus merupakan proses eksplorasi yang mendalam dalam sebuah sistem yang terikat berdasarkan pengumpulan data yang luas (Fitrah, 2017).

Metode yang digunakan ialah naturalistik kualitatif. Penelitian yang tidak menggunakan data statistik, akan tetapi dilakukan melalui proses pengumpulan data, kemudian dianalisi serta diinterpretasikan. Selain itu, posisi peneliti disini sekaligus sebagai instrument kunci (Anggito, 2018).

Pendekatan penelitian naturalistik kualitatif dipilih karena peneliti terlibat langsung dan intensif dalam proses kegiatan Pendidikan Agama Islam di Universitas Islam Indonesia.

Subyek penelitian dalam hal ini adalah pihak yang terkait dengan pelaksanaan kegiatan Pendidikan Agama Islam di perguruan tinggi yakni Direktorat Pembinaan Pendidikan Agama Islam (DPPAI) dan Dosen Mata Kuliah Wajib Umum (MKWU) dalam bidang Pendidikan Agama Islam yang terdapat di Universitas Islam Indonesia. Adapun objek yang terdapat dalam penelitian ini merupakan kegiatan dalam pelaksanaan Pendidikan Agama Islam di Universitas Islam Indonesia.

Dalam proses analisis data menggunakan teknik yang disampaikan Miles dan Huberman seperti di bawah ini:

a. Reduksi data, yakni peneliti membuat rules yang didapatkan melalui catatan lapangan,hasil pengamatan secara akurat, serta wawancara mendalam dan mengkaji dokumen dari "Kurikulum Komperhensif Ulil Albab."

b. Penyajian data, merupakan sekelompok informasi yang tersusun yang digunakan untuk proses pengambilan tindakan.

c. Simpulan, yaitu penarikan inti berdasarkan informasi dan data yang diperoleh dari hasil observasi, informan, dan pengkajian dokumen (Hariyanti, 2015).

\section{Hasil dan Pembahasan}

Universitas Islam Indonesia merupakan universitas Islam yang pertama kali didirikan di Indonesia. 
Keberadaanya merupakan representasi nilai-nilai Islam. Lulusan Universitas Islam Indonesia diharapkan mampu membawa misi yang sama. Misi tersebut diturunkan dalam kurikulum Ulil Albab sebagai acuan atau pedoman bagi seluruh civitas akademik di Universitas Islam Indonesia. Tujuan utama Universitas Islam Indonesia adalah mennjadikan lulusannya memilki profil ulil albab. Profil yang kemudian diterjemahkan dalam berbagai aksi lapangan.

Dalam prespektif A.M. Saefudin, insan Ulil albab merupakan seorang pemikir intelektual yang mempunyai ketajaman berfikir dengan pendekatan ilmiah, namun tetap membangun kepribadiannya dalam kerangka dzikir dan fikir demi dan untuk kemaslahatan umat (Muhaimin, 2003).

Pendapat lain menyatakan Ulil albab merupakan konsep muslim ideal yang memiliki intelektual yang mumpuni dan juga iman yang kuat. Manusia yang mempunyai visi kehidupan yang jelas dan bijak dalam menanggapi masalah (Susanti, 2000).

Di sisi lain, Jalaludin Rahmat mencoba menukilkan istilah Ulil albab dengan Rausyan Fikr yang dikumandangkan oleh Ali Syariati. Pribadi yang kemudian menumpahkan segala akal pikirannya dalam membentuk pribadi muslim yang utuh (Rahmat, 1999). Sedangkan Buya Hamka, mencoba mendefinisikan Ulil albab sebagai manusia yang memiliki kedalaman ilmu pengetahuan dan mempunyai inti pemikiran (Mohd. Arsha, 2015). Sepertinya Hamka lebih menitikberatkan bahwa Ulil albab merupakan manusia yang sudah mencapai level pemikiran diatas ratarata.

Terlepas dari empat tokoh diatas, dapat ditarik benang merah bahwa Ulil albab sendiri merupakan pribadi yang memiliki karakter yang kuat secara ilmiah dan juga secara imaniah.

Keadaan ini tentu ditunjang oleh keinginan yang kuat agar Universitas Islam Indonesia selalu menjadikan nilai Islam sebagai jati diri yang melekat di Perguruan Tinggi ini.

Lulusan yang memiliki profil ulil albab diterjemahkan oleh timUniversitas Islam Indonesia sebagai sebuah proses mutlak untuk mendapatkan lulusan yang diharapkan. Setidaknya ada empat model yang kemudian menjadi komponen 
dalam strategi merevitalisasi Pendidikan Agama Islam (UII, 2017).

Keempat strategi tersebut yang tersebut adalah sebagai berikut: Pertama berkepribadian Islami (sikap). Berkepribadian Islami merupakan pembinaan Pendidikan Agama Islam di Universitas Islam Indonesia.

Pembinaan ini dilaksanakan pada masa orientasi mahasiswa baru yakni melalui kegiatan Penanaman Nilai Dasar Islam (PNDI). Penanaman Nilai Dasar Islam bagi mahasiswa baru bertujuan sebagai "pintu masuk" ke dalam khas Perguruan Tinggi Islam dengan cara internalisasi visi misi hidup, nilai nilai tauhid, ibadah dan akhlak. Hal ini dilakukan dalam rangka membentuk kepribadian Islami mahasiswa.

Kepribadian Islami memang secara perlahan sudah mulai hilang dari diri mahasiswa (Fadillah, 2017). Hal ini tidak terlepas dari munculnya infeltrasi budaya dari luar yang cenderung membuat mahasiswa secara perlahan meninggalkan nilai-nilai Islam.

Kepribadian muslim merupakan kepribadian yang semua agenda hidupnya didasarkan atas kepercayaan terhadap Tuhan dan kemudian diperuntukkan dalam rangka menyerahkan diri pada Tuhannya sehingga menjadi pribadi yang berkualitas dalam menciptakan manusia dengan kompetensi yang unggul (Tatang Hidayat, Ahmad Syamsu Rizal, 2018).

Kedua, Berkepemimpinan profetik (keterampilan umum). Dalam rangka membina mahasiswa memliki jiwa kepemimpinan. Universitas Islam Indonesia melaksanakan Latihan Kepemimpinan Islam Dasar (LKID). Dalam kegiatan LKID ini, mahasiswa diwajibkan belajar tentang bagaimana keberhasilan kepemimpinan yang dilakukan oleh Rasulullah SAW dan para sahabatnya, peran mahassiswa dalam perubahan sosial, prinsip dasar dan karakteristik kepemimpinan dalam Islam, manajeman kepemimpinan dan budaya organisasi.

Internalisasi

pembinaan kepemimpinan melalui Latihan Kepemimpina Islam Dasar (LKID) di atas adalah dalam rangka menjadikan sifat kenabian yang ada pada kepemimpinan Rasulullah untuk dijadikan sebagai model ideal dalam sebuah hierarki organisasi. Kemampuan Rasulullah untuk memberdayakan orang dipimpinannya patut mendapatkan apresiasi dari umat Islam sendri. 
Meskipun tidak bisa dipungkiri bahwa kompetensi ini sungguh sangat berat, di tengah arus informasi yang begitu kuat menjangkau masyarakat dengan berita dan informasi kepemimpinan yang beragam. Kuntowijoyo menjelaskan dengan menggunakan pendekatan Qur'an Surat ke 4 ayat 110 (Masduki, 2017).

Kuntowijoyo menjelaskan dengan menafsirkan adanya tiga poin utama dari ayat tersebut. Pertama terjadinya proses humanisasi, manusia sebagai makhluk sosial diharuskan untuk menyeru kepada yang kebaikan dan kebajiakan. Ini merupakan sebuah kewajiban yang harus diemban manusia. Semua ini tidak bisa dinafikan, bahwa ada kebaikan dan ada kejatahan, keduanya akan selalu bertentangan.

Maka surah Ali-Imran ini menjadi cambuk bagi kita bersama untuk kemudian selalu istiqomah dalam menjalankan perintah Allah dan mau untuk kemudian bergerak dalam rangka menyeru pada kebaikan tersebut.

Kedua, proses liberasi, manusia harus mampu untuk kemudian mencegah hal-hal yang bersifat mungkar. Sebagai mahasiswa, tidak hanya berkutat pada menyeru pada nilai-nilai yang baik, namun juga harus ambil andil dalam upaya mencegah tindakan-tindakan yang mungkar yang tidak selaras dengan nilainilai agama.

Ketiga, transendensi yakni ketika manusia menjalankan kepemimpinan tidak didasarkan nilai naluri semata, tapi lebih dari itu ada sisi religius yang harus menjadi pijakan utama dalam menjalankan kepemimpinan tersebut. Kepemimpinan profetik akan berpengaruh pada pembangunan masyarakat yang madani (Makruf, 2017)

Ketiga, berketerampilan transformatif (keterampilan khusus). Prinsip dasar tentang keterampilan transformatif ini dijelaskan oleh Kristina bahwa nilai transormatif harus didasarkan pada suatu visi besar, yang kemudian dijabarkan dalam aksi dengan usaha-usaha untuk Pendidikan Agama Islam tujuan tersebut (Kristina, 2015). Dalam konteks lebih jauh, keterampilan transformtif ini harus dimiliki oleh mahasiswa baik secara indiviual maupun secara organiasi.

Keterampilan transformatif diejawantahakan dengan dua kompentsi dasar yakni pertama, berorentasi pada penyelesaian masalah. Pola keterampilan ini diimplentasikan sebagai orang yang 
mau dengan semangat inovasi yang dimilikinya menyelesaikan masalah yang dihadapi dengan solusi terbaik. Mahasiswa sebagai agen perubahan harus mampu untuk menjadi solusi terhadap permasalahan yang ada. Solusi ini bisa diterjemahkan secara makro dan bisa juga secara mikro.

Secara makro, berarti mahasiswa secara kolektif memberikan masukan kepada pemerintah untuk melakukan transformasi kebijakan yang berorentasi pada kepentingan, dirubah menjadi oreientasi kesejahtraan sosial. Secara mikro dapat dilihat bahwa sebagai mahasiswa yang sifatnya individu tidak menjadi beban bagi masyarakat. Melainkan mampu untuk menjadi tolak ukur keberhasilan bagi mahasiswa atau masyarakat lainnya.

Kedua, berketrampilan difusif. Dalam keterampilan ini, mahasiswa diharapkan mampu menyebarluaskan gagasannya kepada masyarakat. Ilmu yang sudah didapatkan berguna bagi manusia dan lingkungan. Ilmu tidak berada pada wilayah teori semata, tapi bisa diaplikasikan dalam kehidupan nyata sehingga keterampilan ini menjadi sebuah kekuatan bagi Universitas Islam Indonesia. Dalam hal ini mahasiswa mampu menjabarkan tri dharma perguruan tinggi terhadap persoalan ril yang dihadapi masyarakat.

Lebih jauh, kemampuan mengimplementasikan tri dharma bagi mahasiswa tentu dibekali dengan desain pembelajaran berbasis soft skill sehingga mahasiwa mampu meningkatkan keterampilan pengenalan diri maupun terhadap orang lain (Syahdara Anisa Makruf, 2017) .

Keempat, berpengetahuan integratif (pengetahuan). Pengetahuan tidak hanya bersifat ekslusive, terbatas pada bidang yang ditekuni. Bisa ditunjukkan dengan nilai dan IPK yang didapatkan melalui proses pembelajaran. Namun yang perlu digaris bawahi, lulusan Universitas Islam Indonesia diharapkan memiliki kompetensi yang integratif ke dalam nilai-nilai Islam, terutama Al-quran.

\section{Simpulan}

Temuan dalam penelitian ini terdapatnya beberapa pondasi mendasar untuk merevitalisasi Pendidikan Agama Islam. Pertama, tenaga pendidik harus mempunyai persepsi yang sama terhadap integrasi ilmu dan agama. Kedua, perlu adanya aturan secara detail mengenai 
strategi pembinaan Pendidikan Agama Islam yang termaktub dalam kurikulum ulil albab. Ketiga, bahwa dalam implementasi Pendidikan Agama Islam bukan hanya menjadi tugas Dosen MKWU Pendidikan Agama Islam akan tetapi dilakukan secara holistik. Sehingga keberadaan Universitas Islam Indonesia sebagai pusat keilmuan, pusat keislaman dan pusat inovasi mampu menghasilkan lulusan yang memiliki profil ulil albab yang senantiasa menebarkan risalah Islam Rahmatan Lil Alamin.

\section{E. Daftar Pustaka}

Andri Moewashi Idharoelhaq, M. T. A. (2018). Revitalisasi Pendidikan Karakter melalui Islamisasi Kampus di Universitas

Muhammadiyah Sukabumi. Al Tadzkiyyah, 9(2).

Anggito, A. (2018). Metodologi Penelitian Kualitiatif. Jejak Publisher.

Fadillah, H. (2017). Kesiapan Kerja Dalam Kepribadian Islami Mahasiswa. Jurnal Konseling, 2(3). https://jurnal.umk.ac.id/index.php/g usjigang/article/view/1920

Fitrah, M. (2017). Metodologi penelitian: penelitian kualitatif, tindakan kelas \& studi kasus. CV Jejak.

Hanafi, M. (2014). Pengembangan Kurikulum Perguruan Tinggi Agama Islam. Islamuna: Jurnal Studi Islam. https://doi.org/10.19105/islamuna.v $1 \mathrm{i} 2.572$

Hariyanti, M. (2015). Analisis Data Kualitatif Miles dan Hubermen. In Kompasiana.

Kristina. (2015). Urgensi Kepemimpinan Transformatif Bagi Perpustakaan Perguruan Tinggi. Pustakaloka, $7(1)$.

Makruf, S. A. (2017). Urgensi Kepemimpinan Profetik dalam Mewujudkan Masyarakat Madani. Ta'dib: Jurnal Pendidikan Islam. https://doi.org/10.29313/tjpi.v6i2.3 169

Masduki, M. (2017). PENDIDIKAN PROFETIK; Mengenal Gagasan Ilmu Sosial Profetik Kuntowijoyo. TOLERANSI: Media Ilmiah Komunikasi Umat Beragama. https://doi.org/10.24014/trs.v9i1.43 20

Mohd Arsha, A. (2015). Ulasan Sistematik: Program Ulul Albab 
INTIQAD: JURNAL AGAMA DAN PENDIDIKAN ISLAM

ISSN 1979-9950 (print) || ISSN 2598-0033 (online), http://jurnal.umsu.ac.id/index.php/intiqad

DOI: 10.30596/intiqad.v12i2.5321

Vol. 12, No. 2 (December 2020)

Dalam Sistem Pendidikan Di

Malaysia. Jurnal Kurikulum \&

Pengajaran Asia Pasifik, 3(4).

Muhaimin. (2003). Arah Baru

Pengembangan

Islam,

Pemberdayaan, Pengembangan,

Kurikulum Hingga Redefinisi

Islamisasi Ilmu Pengetahuan.

Muhammad Arif. (2018). Revitalisasi

Pendidikan Aswaja An Nahdliyah

(Ke-Nu-An) Dalam Menangkal

Faham Radikalisme Di Smk Al-

Azhar Menganti Gresik. Jurnal

Penidikan Agama Islam, 5(1).

Rahmat, J. (1999). Islam Alternatif.

Rifqi Amin. (2014). Sistem

Pembelajaran Pendidikan Agama

Islam Pada Perguruan Tinggi

Umum. Deep Publish.

Susanti, S. (2000). Kajian Kritis

Terhadap Konsepsi "Ulil albab"

Dalam Al Qur'an. Ulil Albab.

http://lib.umpo.ac.id/files/6e404-
JURNAL-ulil-albab.pdf

Suwarsono Muhammad. (2020). UII WAY: Menjadi Islami, Indonesiawi dan Mondial . RajaGrafindo Persada.

Syahdara Anisa Makruf. (2017). Urgensi Pembelajaran Soft Skill di perguruan Tinggi. Cendekia, 15(1).

Tatang Hidayat, Ahmad Syamsu Rizal, F. F. (2018). Pendidikan Dalam Perspektif Islam Dan Peranannya Dalam Membina Kepribadian Islami. Mudarrisuna, 8(2).

UII. (2017). Kurikulum Komprehensif Ulil Albab.

Zalik Nuryana. (2017). Revitalisasi Pendidikan al Islam dan Kemuhammadiyahan pada Perguruan Muhammadiyah. TAMADDUN. 